DOI: https://doi.org/10.31933/dijemss.v2i3 Received: 11 November 2020, Revised: 15 December 2020, Publish: 10 February 2021

\begin{tabular}{|c|c|c|}
\hline DINASTIS & $\begin{array}{l}\text { DIJEMSS } \\
\text { DINASTI INTERNATIONAL JOURNAL } \\
\text { OF EDUCATION MANAGEMENT AND } \\
\text { SOCIAL SCIENCE }\end{array}$ & $\begin{array}{r}\text { https://dinastipub.org/DIJEMSS } \\
\text { editor@dinastipub.org } \\
08117401455 \text {. }\end{array}$ \\
\hline
\end{tabular}

\title{
THE IMPLEMENTATION OF BUSINESS MODEL CANVAS (BMC) TO IMPROVE STUDENTS' ENTREPRENEURSHIP MINDSET
}

\author{
Anaseputri Jamira ${ }^{1}$, Nur Agustiningsih ${ }^{2}$, Yulita Febriani ${ }^{3}$ \\ ${ }^{1)}$ University of Batanghari, Jambi, Indonesia, anaseputri.jamira@unbari.ac.id \\ ${ }^{2)}$ University of Batanghari, Jambi, Indonesia, nuragustin216@ gmail.com \\ ${ }^{3)}$ University of Batanghari, Jambi, Indonesia, yulitafebriani585@gmail.com
}

\begin{abstract}
The purpose of this study is to understand the implementation Business Model Canvas (BMC) to improve students' entrepreneurship mindset. There is a gap from previous researches that using traditional research which just focus to develop theory. Action Research gives appropriate approach to improve work or study situation effectively and efficiency. In each cycle in the Level 2 Action Research Method using descriptive statistical analysis techniques through a comparison of the average students' entrepreneurship mindset before and after the application of the BMC method. There are 84 students who participated in this research. The results show that the hypothesis which indicates the BMC method can increase the students' entrepreneurship mindset is empirically proven. The BMC method deserves to be introduced to students. Students have knowledge about how to start a business, and have the courage, ability to create, and innovate and have a high interest in starting a business.
\end{abstract}

Keywords: Business Model Canvas, Entrepreneurship Mindset.

\section{INTRODUCTION}

There are so many definitions of entrepreneurship, but in general entrepreneurship can be defined as the process of identifying, developing and bringing a vision into life, that the vision can be in the form of ideas, opportunities, or an idea or a better way of doing things. Simply put, entrepreneurship is a process of creating jobs for itself. So, it is not surprising to say that entrepreneurship in a broader context can strengthen the economic structure of a country through its contribution to economic development, empowerment and improvement of the quality of resources, creation of jobs, and creating an even distribution of economic and social welfare. This is because the character that is formed from an entrepreneur himself is intelligent and responsive to opportunities, hardworking, consistent, innovative, creative, competitive, and has a learner spirit.

In the ranking of Higher Education in the last period, especially in the Coordination Environment of Private Higher Education (Kopertis) Region X, which is currently, a Higher Education Service Institution (LLDIKTI) Region X is still low. One of the indicators is Student Activities such as Student Entrepreneurship (Kemenristekdikti, LLDIKTI Wil. X, 
2019).

LLDIKTI Region $\mathrm{X}$ continues to strive by promoting various types of seminars, trainings, workshops, to competitions such as the Entrepreneurship Award (EA) which aims to help generate more young entrepreneurs.

To be an entrepreneur with the status of being an active student, these two roles provide both challenges and opportunities. Educated young souls if properly developed will give birth to individuals who have good managerial, product analysis, marketing, operational, financial, human resources, and innovation qualities.

One of the basic methods of designing business ideas and proposals is the Business Model Canvas (BMC) method. This method is a business model analysis tool by presenting data in a simple but comprehensive manner on the nine essential components of a business. This method is so popular and widely used in various research case studies (Hermawan, 2020; Indah, 2020; Kamaluddin, 2020; Agusty, 2020; Nurhayat, 2020; Ojasalo and Ojasalo, 2018; Ruspriono, 2020; Siburian, 2020; Tirtayasa, 2020; Victor, 2020). Even though it is simple, BMC can help in the initial phase of validating a business idea at the planning stage so that it is more mature and ready to run.

This is what underlies the implementation of the Research on the Application of the Business Model Canvas to encourage the entrepreneurship mindset among students of the Faculty of Economics, Batanghari University in 2019/2020. Due to the low interest of students in entrepreneurship, one of which is marked by the low level of student participation in entrepreneurship competitions, especially students of the Faculty of Economics who have studied entrepreneurship courses.

Therefore, the problem examined in this study is how is the application of BMC to encourage the entrepreneurship mindset among students of the Faculty of Economics, Batanghari University in 2019/2020?

The purpose of this study was to determine the application of BMC to encourage the entrepreneurship mindset among students of the Faculty of Economics, Batanghari University in 2019/2020.

The urgency of this research is to encourage the growth of entrepreneurs or aspiring young entrepreneurs who are qualified in conducting business planning thoroughly with the BMC method, as well as encouraging and supporting the development of entrepreneurial learning in Higher Education.

\section{LITERATURE REVIEW \\ Business Model Canvas}

The canvas business model is one of the most popular business models in use today. The canvas business model is depicted through nine basic building blocks that show the logic of how a company intends to make money. These nine blocks cover the four main business areas namely customer, offering, infrastructure, and financial feasibility.

In a book entitled "The Startup Owner's Manual: The Step-by-Step Guide for Building a Great Company", written by Steve Blank and Bob Dorf (2012), is explained the nine elements in the business model canvas (customer segment, value propositions, channels, 
customer relationships, revenue streams, key resources, key activities, key partners, and cost structure).

In running its business, the organization must first determine who should be served. Organizations can assign to serve one or more segments. This segment assignment will determine other components in the business model. This customer segment element/block describes who will be the target market for the goods or services offered.

Value propositions are the benefits or value that the company offers to the market segments it serves. This value offering is also the reason why customers should buy the goods or services offered.

Channels are a means for companies to deliver Value Propositions to the Customer Segments served. They are canal for connecting with customers.

Customer relationships are the means by which a company maintains a good relationship with its customers.

Revenue Streams are the revenue that the company receives from each market segment, or in other words, revenue streams are income which is usually measured in terms of the money that the company receives from its customers.

Key resources are the main resources a company must have to run a business. Generally, the resources needed are in the form of human, technological, financial, and physical resources (raw materials and other materials).

Key activities are the main activities that must be controlled by a company to run a business. In manufacture industries, activity components are divided into three parts, namely the procurement of raw materials, processes and marketing.

Key partners are the resources needed by the company to realize its value proposition, but not owned by the company. Utilization of Key Partners by companies can be in the form of outsourcing, joint ventures, joint operations, or strategic alliances.

Cost Structure is the composition of costs to operate a business in realizing the value proposition it provides to customers. It describes as the cost structures involved in the business, both fixed and variable costs, maintenance costs, operational costs, etc.

Prof. Hong Y. Ching and Clemens Fauvel (2013) highlight the importance of using BMC and recommend it for entrepreneurs and academics. BMC helps budding entrepreneurs develop business plans and have a more holistic understanding of their business.

Alexander Osterwalder and Yves Pigneur (2010), introduced the concept of a business model that everyone can understand, starting from the same point and talking the same thing, with concepts that are simple, relevant, and intuitive to understand, while not overly simplifying the complexity of how the company functions.

\section{Entrepreneurship Mindset}

Entrepreneurship is the creation of wealth through innovative employment and economic growth centers, and the sharing of wealth that relies on hard work and risk taking. 
Adi W. Gunawan (2008) in his book The Secret of Mindset, mindset consists of two words, namely Mind and Set. Mind means thought, or commonly referred to as a source of consciousness that can generate thoughts, ideas, feelings and perceptions, and can store memories and knowledge. Set is a state of being intact or giving priority to increased ability in an activity. So it can be drawn a common thread that the mindset is a set of beliefs and ways of thinking that can determine a person's outlook, behavior, attitudes and also the future.

There are 7 mental attitudes that aspiring entrepreneurs need to have (McGrath and MacMillan, 2000), namely:

1) Action oriented. They are people who want to act immediately even if the situation is uncertain.

2) Think simple. They always learn to simplify, not complicated humans. They see problems clearly and solve problems gradually.

3) They always look for new opportunities. Always be creative.

4) Pursue opportunities with high discipline. Opportunities are not only sought after, but created, opened and clarified.

5) Take only the best possible opportunities. It's associated with "liking" to the object of the business or the belief that he is "able" to make it happen.

6) Focus on execution. No doubt.

7) An entrepreneur does not work alone. He worked in teams, involved people and built networks.

According to Ita Athia, Ety Saraswati, and Andi Normaladewi (2018) that the Entrepreneurship Mindset can be seen from 5 factors, namely how much interest in entrepreneurship is, knowledge held about business components, knowledge about how to start a business, courage to create a business, and the ability to create and innovate.

\section{RESEARCH METHODS}

Previous research by Ita Athia, Ety Saraswati, and Andi Normaladewi (2018) used a literature research method which studies interesting topics or is traditional research whose research results are limited to theory development. This is deemed inappropriate, considering that research focuses on the aspects of its application.

There is a gap from previous research, the background for the use of the Action Research Method. The Action Research Method, also known as Participatory Research, Collaborative Inquiry, Emancipatory Research, Action Learning, and Contextual Action Reseach, according to Sugiyono (2015), is a research approach with two (dual) objectives, namely taking new effective and efficient actions to improve the work situation (take action) and to develop a science/ knowledge or theory of action (science of action). It is different from traditional research which only focuses on theory development.

Action research is a type of applied research that aims to facilitate social change. Action research is practical research. The chosen action has been proven through research. So, action research is used to find knowledge about how to make improvements.

There are four levels/ designs in action research. Level 1 of action research is action research that the researcher conducts research to identify potentials and problems, and then 
the researcher provides suggestions for action, but does not test the action.

Level 2 of action research is action research that the researcher does not conduct research to identify potentials and problems (only reflecting), but directly tests an action plan that is believed to solve problems or improve performance.

Level 3 of action research is action research that the researcher conducts research to find problems and potentials, and then the researcher develops existing actions and tests these actions.

The last is Level 4 of action research is action research that the researcher conducts research to find problems and potentials, and then the researcher finds or creates new actions and tests these actions. In terms of science and methodology, the highest level of action research is Level 4 of action research.

The research that will be carried out by the Researcher is Level 2 of Action Research, because the research problem is already known, that's the lack of student interest in entrepreneurship and how to encourage the entrepreneurship mindset of students with a method or theory that has been tested (using BMC). So, it just does reflection.

Action research in terms of number of actions and results of action is divided into simple action research and multiple action research. This research uses simple action research.

This research was conducted in a small work unit, that is the scope of the Faculty of Economics, University of Batanghari, Jambi City, Sumatera - Indonesia.

The sampling technique in this study is to use a quota sampling technique which is a non-probability sampling technique. This technique determines a sample of a population that has the characteristics of the provisions up to the desired quota (Sugiyono, 2019). The reason this sampling technique was chosen, that's to meet strict health protocol standards in the face of Covid-19.

This Level 2 of action research method was carried out by repeated experiments, with three cycles. The experiment is "before-after", by comparing the entrepreneurship mindset before and after using the BMC method. Each cycle of testing the action hypothesis is carried out with four processes. They are planning, implementation, observation, and reflection.

The research was conducted for three meetings, two meetings are face-to-face sessions (tutorial class), and one meeting is video conference session (virtual class). Data collection techniques are used with observation and documentation.

The research instrument used was the entrepreneurship mindset assessment questionnaire filled out by students using a Likert scale with levels $1-4$ on five aspects of the entrepreneurship mindset. They are how much interest in entrepreneurship; knowledge held about business components; knowledge of how to start a business; courage to create business; and the ability to create and innovate. The meaning of the number $4=$ Very High $(\mathrm{ST}) ; 3$ = High $(\mathrm{T}) ; 2=\operatorname{Enough}(\mathrm{C})$; and 1 = Low $(\mathrm{R})$.

Data analysis to test hypotheses in each cycle used descriptive statistical analysis 
techniques, which is through comparison of the average student entrepreneurship mindset before and after the application of the BMC method.

The action hypothesis in this study is: The BMC method can increase the Entrepreneurship Mindset of Students of the Faculty of Economics, University of Batanghari.

\section{FINDINGS AND DISCUSSION}

Before the action at the initial stage, a survey was conducted to determine the condition of the entrepreneurship initial mindset of 84 samples of students from the Faculty of Economics, University of Batanghari.

Table 1 shows that the entrepreneurship mindset of students before the application of the BMC Method was 42 people $(50 \%)$ were in the low category, 16 people $(19,05 \%)$ were in the moderate category, 21 people $(25 \%)$ were in the high category, and 5 people $(5,95 \%)$ is in the very high category. It appears that most of the student entrepreneurship mindset is still in the low category.

Table 1. The Results of The Recapitulation of Student Entrepreneurship Mindset Observations Before The Action

\begin{tabular}{cccc}
\hline No. & Scale & Frequency & $\begin{array}{c}\text { Percentage } \\
(\mathbf{\%})\end{array}$ \\
\hline 1 & $\begin{array}{c}\text { Very } \\
\text { High }\end{array}$ & 5 & 5,95 \\
\hline 2 & High & 21 & 25 \\
\hline 3 & Enough & 16 & 19,05 \\
\hline 4 & Low & 42 & 50 \\
\hline \multicolumn{5}{r}{ Source: Processing by Researcher $(\mathbf{2 0 2 0})$}
\end{tabular}

In the first cycle of action, planning for testing, implementing, acting, observing, and reflecting based on the results of the observations is shown in Table 2. It can be seen that the entrepreneurship mindset of students has increased quite high, that for the low category, which was originally $50 \%$ changed to $25 \%$, initially enough category $19,05 \%$ increased to $29,76 \%$, high category from $25 \%$ to $29,76 \%$, and very high category $5,95 \%$ to $15,48 \%$.

This shows that the application of the BMC Method in the first cycle can increase the entrepreneurship mindset of students. The results of the reflection in the first cycle will be tested for consistency in the second cycle.

Table 2. The Results of The Recapitulation of Student Entrepreneurship Mindset Observations After The First Cycle of Action

\begin{tabular}{cccc}
\hline No. & Scale & Frequency & $\begin{array}{c}\text { Percentage } \\
(\boldsymbol{\%})\end{array}$ \\
\hline 1 & Very High & 13 & 15,48 \\
\hline
\end{tabular}




\begin{tabular}{cccc}
2 & High & 25 & 29,76 \\
\hline 3 & Enough & 25 & 29,76 \\
\hline 4 & Low & 21 & 25 \\
\hline & Total & $\mathbf{8 4}$ & $\mathbf{1 0 0}$ \\
\hline & Source: Processing by & Researcher $\mathbf{( 2 0 2 0 )}$
\end{tabular}

Based on Table 3, it can be seen that most students become more motivated to become entrepreneurs. In general, the percentage of students who have a high and very high entrepreneurship mindset reaches $51,19 \%$.

This shows that the application of the BMC Method in the second cycle can increase the entrepreneurship mindset of students.

Table 3. The Results of The Recapitulation of Student Entrepreneurship Mindset Observations After The Second Cycle of Action

\begin{tabular}{cccc}
\hline No. & Scale & Frequency & Percentage (\%) \\
\hline 1 & Very High & 16 & 19,05 \\
\hline 2 & High & 27 & 32,14 \\
\hline 3 & Enough & 26 & 30,95 \\
\hline 4 & Low & 15 & 17,86 \\
\hline & Total & $\mathbf{8 4}$ & $\mathbf{1 0 0}$ \\
\hline & Source: Processing by Researcher $\mathbf{( 2 0 2 0 )}$
\end{tabular}

The results of the reflection in the second cycle were tested again for consistency in the third cycle. The results are shown in the fourth table.

Table 4. The Results of The Recapitulation of Student Entrepreneurship Mindset Observations After The Third Cycle of Action

\begin{tabular}{|c|c|c|c|}
\hline No. & Scale & Frequency & Percentage (\%) \\
\hline 1 & Very High & 21 & 25 \\
\hline 2 & High & 30 & 35,71 \\
\hline 3 & Enough & 27 & 32,14 \\
\hline \multirow[t]{2}{*}{4} & Low & 6 & 7,15 \\
\hline & Total & 84 & 100 \\
\hline
\end{tabular}

Based on Table 4, the number of students who have a high and very high entrepreneurship mindset reaches $60,71 \%$, more than students who have a fairly low and low entrepreneurship mindset, they are only $39,29 \%$. 


\section{CONCLUSION AND SUGGESTION}

After the application of the BMC Method, the percentage of students who have a high entrepreneurship mindset tends to continue to increase. In the first cycle there was an increase of $46,17 \%$, in the second cycle it increased to $65,40 \%$, and in the third cycle it increased to $96,16 \%$.

Based on the discussion of the research results, it can be concluded that the hypothesis which states that the BMC method can increase the entrepreneurship mindset of the students of the Faculty of Economics, University of Batanghari is empirically proven or acceptable.

The BMC method is feasible to be introduced and taught to students in entrepreneurship courses, so that the entrepreneurship mindset can be instilled in students in a more structured manner.

Students have a good understanding of knowledge about how to start a business and it's components, and have the courage, ability to create and innovate, and have a high interest in starting a business.

The scope of this research is small, limited to only one Faculty of a College or University, and uses Level 2 of Action Research Method, in the future the scope of research can be expanded to the National level, and uses the highest level of action research method, Level 4 of Action Research.

\section{REFERENCE}

Agusty, Rosana Mia. 2020. Designing Business Model Canvas Transforms Into Balanced Scorecard in the XYZ University in Indonesia. Dinasti International Journal of $\begin{array}{lllll}\text { Management } & \text { Science. } & 1, & 6 & \text { (Jul. 2020), }\end{array}$ https://doi.org/10.31933/dijms.v1i6.392

Athia, Ita, Saraswati, Ety, and Normaladewi, Andi. 2018. Penerapan Business Model Canvas (BMC) untuk Mendorong Mindset Kewirausahaan di Kalangan Mahasiswa Universitas Islam Malang. Jurnal Ketahanan Pangan, 2(1), 66-75. http://riset.unisma.ac.id/index.php/JU-ke/article/view/1051/1086

Blank, Steve, and Dorf, Bob. 2012. The Startup Owner's Manual: The Step-by-Step Guide for Building a Great Company. United State of America: K\&S Ranch.

Ching, Hong Y., and Fauvel, Clemens. 2013. Criticisms, Variations and Experiences with Business Model Canvas. European Journal of Agriculture and Forestry Research, 1(2), 26-37. http://www.eajournals.org/wp-content/uploads/Criticisms-Variations-andExperiences-with-Business-Model-Canvas.pdf

Gunawan, Adi W. 2008. The Secret of Mindset. Jakarta: Gramedia Pustaka Utama.

Hermawan, Frendy. 2020. Analysis of Family Business Development Model Based on Business Model Canvas (Case Study in CV. MXY). Dinasti International Journal of Digital Business Management, 1(5), 829-841. https://dinastipub.org/DIJDBM/article/view/486

Indah, RA. Iis Suci Nur. 2020. Planning Business Model Canvas with SWOT Method at XYZ 
Institute. Dinasti International Journal of Digital Business Management, 1(5) 781-793. https://dinastipub.org/DIJDBM/article/view/483

Kamaluddin, Iqbal. 2020. Business Development Strategy with Canvas Model Business Approach in CV. Hakhenbik. Dinasti International Journal of Economic, Finance, and Accounting, 1(3), 469-481. https://doi.org/10.38035/dijefa.v1i3.431

Kemenristekdikti, LLDIKTI Wil. X. 2019. Panduan Entrepreneurship Award III-2019. Unpublished. Padang: LLDIKTI Wil. X.

McGrath, Rita Gunther, and MacMillan, Ian. 2000. The Entrepreneurial Mindset: Strategies for Continuously Creating Opportunity in an Age of Uncertainty. Boston, Massachusetts: Harvard Business School Press.

Nurhayat, Kartika. 2020. Designing Business Canvas Model and Analysis Business in Warung Dimsum. Dinasti International Journal of Management Science, 1(6), 903912. https://doi.org/10.31933/dijms.v1i6.398

Ojasalo, Jukka, and Ojasalo, Katri. 2018. Service Logic Business Model Canvas. Journal of Research in Marketing and Entrepreneurship: Emerald Publishing Limited, 20(1), 1471-5201.

https://www.researchgate.net/publication/338300234_Service_Logic_Business_Model _Canvas_for_Lean_Development_of_SMEs_and_Start-Ups

Osterwalder, Alexander, and Pigneur, Yves. 2010. Business Model Generation: A Handbook for Visionaries, Game Changers, and Challengers. Hoboken, New Jersey: $\begin{array}{llll}\text { John Wiley } \& \text { Sons, } & \end{array}$ https://www.academia.edu/18868178/Business_Model_Generation_A_Handbook_for _Visionaries_Game_Changers_and_Challengers

Ruspriono. 2020. Business Analysis Model Using Canvas Business Model Approach to KJPP Yanuar Bey and Partners. Dinasti International Journal of Digital Business Management, 1(4) 608-617. https://dinastipub.org/DIJDBM/article/view/370

Siburian, Agus Mangiring. 2020. Implementation of Business Model Canvas in Chemical Manufacturing Company PT. Timuraya Tunggal. Dinasti International Journal of Economic, Finance, and Accounting, 1(3), 421-430. https://dinastipub.org/DIJEFA/article/view/421

Sugiyono. 2015. Metode Penelitian Tindakan Komprehensif. Bandung: Alfabeta.

Sugiyono. 2019. Metode Penelitian Pendidikan. Bandung: Alfabeta.

Tirtayasa, Yohan. 2020. Canvas Business Strategy in the Aapplication of Local Credits in Bank BCA. Dinasti International Journal of Management Science, 1(6), 854-862. https://doi.org/10.31933/dijms.v1i6.394

Victor. 2020. Business Analysis of Canvas and SWOT Models (Case Study for Culinary Crossbreed Cake "Tn. Xyz"). Dinasti International Journal of Economic, Finance, and Accounting, 1(3), 515-525. https://dinastipub.org/DIJEFA/article/view/451 